\title{
Estados del arte. Puestas en escena de construcciones históricas e imaginarias durante el Bicentenario en Argentina
}

\author{
State(s) of the art(s). Stagings of Historial and Imaginary \\ Constructions during Bicentennial Celebration in Argentina \\ Estados da arte. Postas em cena de construções históricas \\ e imaginárias durante o Bicentenário na Argentina
}

\section{Viviana Usubiaga}

UNIVERSIDAD DE BUENOS AIRES/UNIVERSIDAD NACIONAL DE SAN MARTÍN/UNIVERSIDAD NACIONAL DE TRES DE FEBRERO/CONSEJO NACIONAL DE INVESTIGACIONES CIENTÍFICAS Y TÉCNICAS, ARGENTINA

Profesora en la Facultad de Filosofía y Letras de la Universidad de Buenos Aires y profesora de posgrado en el Instituto de Altos Estudios Sociales de la Universidad Nacional de San Martín y en la Universidad Nacional de Tres de Febrero, Argentina. Doctora en Historia y Teoría de las Artes por la Universidad de Buenos Aires. Investigadora del Consejo Nacional de Investigaciones Científicas y Técnicas (Conicet). Editora de la revista Blanco sobre Blanco. Miradas y Lecturas sobre Artes Visuales. Coautora de Arte y literatura en Argentina del siglo $X X$ (Fundación Espigas, 2006). Autora del libro Imágenes inestables. Artes visuales, dictadura y democracia en Buenos Aires (Edhasa, 2012), entre otras publicaciones. Correo electrónico: vusubiaga@gmail.com

\footnotetext{
Artículo de reflexión

Documento accesible en línea desde la siguiente dirección: http://revistas.javeriana.edu.co doi:10.11144/Javeriana.cl20-40.eape
}

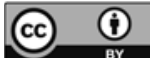




\section{Resumen}

El artículo problematiza los vínculos entre conocimiento histórico y ficción artística a partir del análisis de obras y acontecimientos artísticos contemporáneos basados en un capítulo fundante para la historia del arte argentino de fines de siglo XIX - el duelo intelectual y físico que mantuvieron Eduardo Schiaffino y Eugenio Auzón en 1891-; la proyección de ese episodio en la primera década del siglo XXI, precisamente en el contexto del Bicentenario de la Revolución de Mayo, con la obra teatral Apátrida. Doscientos años y unos meses del dramaturgo Rafael Spregelburd, y otras producciones de artistas contemporáneos como Marcos López, Marcela Sinclair y Santiago Villanueva. Desde una multiplicidad de nuevas miradas sobre aquel episodio remoto se establece un recorrido entre documentos, textos, imágenes, performances y sonidos, con el objetivo de reflexionar sobre los estados del arte durante las celebraciones del Bicentenario de la nación argentina.

Palabras clave: artes visuales; teatro; crítica; historia; Bicentenario; Argentina

\section{Abstract}

This article aims to contribute to the current discussion about historial knowledge and art fiction links by focusing on the analysis of contemporary art works and events based on an Argentine Art History founding chapter from late 19th century-Eduardo Schiaffino and Eugenio Auzon's intellectual and physical duel hold in 1891; by examining that episode's effects towards the beginning of 21 th century, and the duel reactualized within the context of the Bicentennial celebration of the May Revolution, through the stanging of Rafael Spregelburd's play Doscientos años y unos meses, and also focusing on other works made by contemporary artists such as Marcos Lopez, Marcela Sinclair and Santiago Villanueva. The article sets a route through selected documents, texts, images, sounds and performances in order to reflect on the state(s) of the art(s) during the Bicentennial of Argentine Nation.

Keywords: visual arts; drama; criticism; history; Argentina bicentennial

\section{Resumo}

$\mathrm{O}$ artigo problematiza as ligações entre conhecimento histórico e ficção artística a partir da análise de obras e fatos artísticos contemporâneos baseados em um capítulo fundante da história da arte argentina de finais dos oitocentos -o duelo intelectual e físico que mantiveram Eduardo Schiaffino e Eugenio Auzón em 1891—; a projetação desse episódio na primeira década do século XXI, precisamente no contexto do Bicentenário da Revolução de Maio, com a obra teatral Apátrida. Duzentos anos e uns meses do dramaturgo Rafael Spregelburd, e outras produções de artistas contemporâneos como Marcos López, Marcela Sinclair e Santiago Villanueva. Desde uma multiplicidade de novos olhares sobre tal episódio remoto estabelece-se um percurso entre documentos, textos, imagens, performances e sons, a fim de refletir sobre os estados da arte durante as comemorações do Bicentenário da nação argentina.

Palavras-chave: artes visuais; teatro; crítica; história; Bicentenário; Argentina

RECIBIDO: 8 DE AGOSTO DE 2015. ACEPTADO: 11 DE OCTUBRE DE 2015. DISPONIBLE EN LÍNEA: 1 DE JULIO DE 2016

Cómo citar este artículo:

Usubiaga. Viviana. "Estados del arte: puestas en escena de construcciones históricas

e imaginarias durante el Bicentenario en Argentina". Cuadernos de Literatura

20.40 (2016): 155-180. http://dx.doi.org/10.11144/Javeriana.cl20-40.eape 
"Un Estado es la historia de sus ficciones. La suma de sus imágenes". EDUARDO SCHIAFFINO (1891), SEGÚN RAFAEL SPREGELBURD

"El concepto viaja varias veces entre la práctica (artística) y la teoría (académica), y entre la práctica (académica) y la teoría (artística)".

MIEKE BAL

Este ARTíCULO - BASADO en hechos casi reales- propone pensar las relaciones productivas entre conocimiento histórico y ficción artística mediante la saga de obras y acontecimientos producidos a partir de un capítulo fundante para la historia del arte argentino de fines de siglo XIX y la proyección de ese episodio "recargado" en la primera década del siglo XXI. Desde el análisis cultural busco formular un "viaje", en el sentido que sugiere Mieke Bal, cuando postula la necesidad de transitar "la laberíntica tierra de las humanidades, sin fronteras" a través del "aprendizaje de lenguas extranjeras y del encuentro con los otros" (16). Se trata de un viaje a través de documentos, textos, imágenes, performances y sonidos con el objetivo de reflexionar sobre los estados del arte en un juego múltiple de sentidos, que abarca la actual elasticidad, permeabilidad y porosidad de los objetos artísticos, lo cual da lugar tanto a extraordinarias transposiciones de lenguajes simbólicos como a complejas construcciones imaginarias del pasado y el presente de un Estado (con mayúsculas) como el argentino.

En otras palabras, a lo largo del artículo orbitarán varias acepciones del término estado: primera, como la situación en la que se encuentra algo (el estado del arte contemporáneo); segunda, referido al conjunto de instituciones políticas constitutivas de una nación (el Estado argentino); tercera, pensado el estado del arte equivalente al estado de la cuestión en torno al desarrollo de una disciplina (la historia del arte, la crítica cultural), y, por último, al uso dado en la práctica de esgrima donde se llama precisamente estado a la disposición o la figura en la que queda el cuerpo después de haber herido al contrario. Tal como se verá en las páginas que siguen, esta última curiosa acepción acierta en un punto común con los objetos que examinaré.

\section{Escena uno. Una exposición de arte argentino}

El 28 de noviembre de 1891 abrió sus puertas una exposición artística, históricamente asumida como la primera muestra de arte argentino. Fue organizada por la 
Sociedad de Beneficencia de Nuestra Señora del Carmen junto a una comisión integrada por varios de los mismos artistas participantes en la casa de remates de Belisario García, situada en la calle Florida de la ciudad de Buenos Aires. Junto a una serie de pinturas europeas, se expusieron obras de los artistas argentinos considerados los "primeros modernos" (Malosetti Costa) en la Argentina de finales del siglo XIX: Augusto Ballerini, Reinaldo Giudici, Ángel Della Valle, Eduardo Sívori, Eduardo Schiaffino, Severo Rodríguez Etchart, Graciano Mendilaharzu, Lucio Correa Morales y Sofía Posadas. Varios de ellos exponían sus cuadros por primera vez en la ciudad luego de sus viajes de formación en Europa - algunos habían sido becados por el Gobierno-y se encontraban de regreso en Buenos Aires. Entre otros episodios significativos que se produjeron durante la exposición ${ }^{1}$ cabe mencionar un acto de censura cuando las damas organizadoras decidieron retirar un pastel realizado por la única pintora participante. Idilio era el título del estudio de torso desnudo que fue blanco selectivo de la moral de entonces; moral de la que se filtraron otros desnudos presentes en la muestra. Sin duda, el pecado de Sofía Posadas había sido el escapar a los temas apropiados para las artistas mujeres de entonces, que eran las flores, las frutas, los niños y, con menor frecuencia, los retratos. El exabrupto llegó a la prensa repudiado por artistas y críticos. Al respecto, un cronista llegó a instalar la pregunta retórica: " ¿ $\mathrm{C} D$ cuántos ignorantes se compone un público?" (“Arte a sablazos"1). Un ícono de la literatura argentina de presencia recurrente en la muestra fue también blanco de las discusiones en la prensa. Las pinturas sobre Juan Moreira, el gaucho ficcionado en la novela de Eduardo Gutiérrez, iniciaron una controversia insalvable sobre cuál debía ser la iconografía adecuada para la pintura argentina.

\section{Escena dos. Un duelo por amor al arte}

Fue luego del cierre de la exposición, en diciembre de 1891, cuando Eduardo Schiaffino (pintor y crítico argentino fundador del Museo Nacional de Bellas Artes, pocos años después) protagonizó un duelo intelectual y físico junto al pintor y crítico nacido en España, Max Eugenio Auzón, a causa de la posible existencia de un arte argentino. Sus misivas de altísimo voltaje literario guardan un caudal de juicios sobre temas recurrentes en la historia cultural de Argentina: la definición de un arte nacional, la competencia de los artistas, la profesionalización y función de la crítica, la institucionalización del circuito, los modelos foráneos y su relación con la identidad nacional, el rol del Estado en la cultura o el problemático estado

\footnotetext{
1 Para un análisis exhaustivo sobre la exposición referida véase el artículo de mi autoría "Pinceles, plumas y sables", de 1999.
} 
de situación la cultura. La polémica estalló con la provocación de Auzón, escrita bajo el seudónimo de A.Zul de Prusia, en la que espetaba: “QQué necesidad de ir á estudiar a Europa cuando aquí tenemos el cielo de Nápoles, la luna de todas partes, el sol de Austerlitz y una cordillera que se ríe a carcajadas de los Alpes? Pero que arte nacional ni que berengenas! es inútil pensar en ello hasta dentro de 200 años y un par de meses" ("El crítico". La acentuación y ortografía es la original). De inmediato, Schiaffino le respondió en nombre del interés de "los artistas nacionales" y ante la polémica encendida ya no hubo retorno.

Las mutuas ofensas llevaron a Auzón a exigir la "reparación en armas". Así fue como el desacuerdo entre las partes llegó a materializarse en un duelo de sables el 25 de diciembre de 1891 en una quinta en el partido de Morón. En el segundo asalto, Schiaffino fue herido en la mano derecha y se suspendió el combate. Los adversarios retiraron las palabras ofensivas frente a sus padrinos Mariano Mansilla y Félix Alberto Zavalía, por Auzón, y Aristóbulo del Valle y Pedro O. Luro, por Schiaffino. No obstante, sus diferencias, en las que cuajan dos modelos de entender el desarrollo de las artes y su vínculo conflictivo con el Estado nacional, no se saldaron en aquel campo. Sobre este apasionado debate que involucró una relación estética entre arte y política cabe recordar lo que sostiene Jacques Rancière al respecto:

El régimen estético del arte implica en sí mismo una determinada política, una determinada reconfiguración de la división de lo sensible. [...] El disenso no es en principio un conflicto entre los intereses o las aspiraciones de diferentes grupos. Es, en sentido estricto, una diferencia en lo sensible, un desacuerdo sobre los datos mismos de la situación, sobre los objetos y sujetos incluidos en la comunidad y sobre los modos de su inclusión. (55)

De alguna manera, las discrepancias entre estos dos intelectuales decimonónicos pueden considerarse de grado si se piensa que ambos contrincantes pertenecían a la misma élite porteña. De todos modos, la historia parece haberse encargado de condenar a Auzón como el vencedor vencido. Se había prescindido de su figura hasta hace pocos años. En cambio, Schiaffino ha sido insoslayable para la historia del arte argentino, por su accionar como artista, crítico, gestor y fundador de instituciones centrales para la conformación del campo artístico, como el Museo Nacional de Bellas Artes, hasta llegar a ser cónsul argentino en Europa. Sus pinturas se han revalorizado y se conservan en museos, y hasta una calle de la ciudad de Buenos Aires lleva su nombre - aunque, debemos decir, recientemente el nombre del escritor Adolfo Bioy Casares le robó una cuadra, por decreto municipal-. 
Max Eugenio Auzón fue en realidad secretario de ministros y hombres de Gobierno. Continuó su labor de crítico corrosivo y, en menor proporción, de pintor - tal vez por eso sus pinturas son hasta ahora inhallables. Tuvo una vida "honesta y ruidosa", según se lo describe en una entrevista publicada en la revista El Hogar, en 1927, cuando, ya jubilado, casi ciego, "olvidado en un rincón de Buenos Aires", recuerda aquel "duelo por amor al arte". Allí se lo caracteriza como un hombre "elevado" y honesto. El cronista relata "[...] pudo cuando fue secretario de ministros aprovechar su puesto para enriquecerse, máxime cuando [el político y escritor Eduardo] Wilde, por ejemplo, le confiaba la solución de muchas negociaciones financieras del país" (Ruiz Palenzuelos 17). Una posibilidad que parecía haber desaprovechado según la falsa moral reinante (ayer y hoy) que se expresa en una anécdota en la cual la mujer de Wilde, Guillermina Oliveira Cézar, le preguntó sorprendida a Auzón: "—¡Cómo! ¿No es usted rico? ${ }_{\mathrm{i}} \mathrm{No}$ ha manejado usted dinero del Estado durante treinta años? —Sí, señora. Por eso mismo [... traté siempre de tener las manos limpias" (Ruiz Palenzuelos 17 y 94). ${ }^{2}$

El recuerdo de aquella contienda perdió nitidez con el tiempo. Quizás pudiéramos encontrar a los duelistas reencarnados en los pinceles de Clara y Marta, protagonistas del cuento "El duelo", de Jorge Luis Borges, incluido en su libro El informe de Brodie. El célebre escritor argentino escribió: "Clara [...] pintaba contra Marta y de algún modo para Marta; cada una era juez de su rival y el solitario público. En esas telas, que ya nadie miraba, creo advertir, como era inevitable, un influjo recíproco" (101). Precisamente allí, entre aquel duelo íntimo, se inscriben las preguntas recurrentes que Borges formula imbricadas en su ficción. Haciendo alusión al temario "de palpitante interés" de un Congreso Internacional de Plásticos Latinoamericanos detalla: " ¿puede el artista prescindir de lo autóctono, puede omitir o escamotear la fauna y la flora, puede ser insensible a la problemática de carácter social, puede no unir su voz a la de quienes están combatiendo al imperialismo?". Beatriz Sarlo ha escrito que "En estos relatos [de Borges], el tema filosófico de los dobles que ignoran que, a través de ellos, se cumplen destinos repetidos infinitamente, diluye la aventura del coraje en un espacio siniestro donde los personajes repiten acciones sin saber que son impulsados por fuerzas muy diferentes de las que creen reconocer en sus actos". Algo acerca de estas acciones y destinos repetidos en los que persisten las preguntas siempre latentes sobre la representación de una identidad nacional se verifica también en los casos que siguen.

2 Agradezco el hallazgo de esta referencia al historiador Pablo Montini. 


\section{Escena tres. Componiendo un pastiche de registros históricos}

Un siglo y unas décadas después de aquel duelo, más precisamente, durante las celebraciones del Bicentenario de la Argentina, el dramaturgo y actor Rafael Spregelburd (Buenos Aires, 1970), junto al músico y compositor Federico Zypce (Buenos Aires, 1973), estrenó una obra titulada Apátrida. Doscientos años y unos meses (figura 1). La creación de esta pieza escénica - en rigor, una ópera habladase basó en el rescate histórico de las fuentes documentales de aquella polémica entre Schiaffino y Auzón que Spregelburd tuvo oportunidad de conocer a través de lo que podría definirse como otro tipo de performance escénica - esta vez en la arena académica-: la presentación de una ponencia en unas jornadas de investigación en el ámbito universitario. ${ }^{3}$ Aquel episodio de la historia del arte argentina conservaba para Spregelburd una intensidad dramática singular. Su teatralidad en potencia lo llevó a revisar los materiales documentales más de una vez a lo largo de años hasta encontrar el momento preciso para la escritura de una obra que los revisitara. Tras más de una década, en las vísperas del Bicentenario de la Revolución de Mayo de 1810, se conjugaron ciertas circunstancias que lo llevaron a concretar la escritura de su pieza teatral. Las conmemoraciones de la revolución independentista establecieron una agenda pública propicia para los balances historiográficos y los proyectos artísticos y expositivos que apuntaron reflexiones sobre las tensiones y conflictos entre pasado y presente.

En abril de 2010, un grupo de historiadoras del arte - entre las que me incluyo- invitó a Spregelburd a escribir un artículo inspirado en el intercambio epistolar de Schiaffino y Auzón. Este fue incluido en un proyecto editorial que estaban desarrollando para un concurso de nuevas revistas culturales de la Secretaría de Cultura de la Nación, vinculado asimismo a las celebraciones del Bicentenario. El certamen requería la presentación de un número cero. Entre las secciones ideadas por las editoras para el proyecto de la revista que habría de llamarse Blanco sobre Blanco. Miradas y Lecturas sobre Artes Visuales, idearon una dedicada a "propiciar un encuentro poco probable": el de alguien en principio ajeno a las artes plásticas - fue el caso del dramaturgo - con una serie dada de documentos rescatados de la historia del arte. Para aquella primera "Versión libre", así se dio en llamar la sección, Spregelburd escribió una disquisición interceptada

3 En este caso fue en septiembre de 1998 cuando siendo estudiante avanzada de la carrera de Artes de la Facultad de Filosofía y Letras de la Universidad de Buenos Aires expuse el trabajo "Pinceles, plumas y sables. La exposición artística de 1891" en las jornadas de investigación organizadas por el Instituto de Teoría e Historia del arte Julio E. Payró. Tuve oportunidad de comentar acerca del hallazgo y rescate de aquellas cartas en una crónica distendida en el suplemento cultural Radar del diario Página 12 (Usubiaga, "Del microfilm" 7). 
por las cartas originales, que puede considerarse un primer boceto de su obra Apátrida. Doscientos años y unos meses.

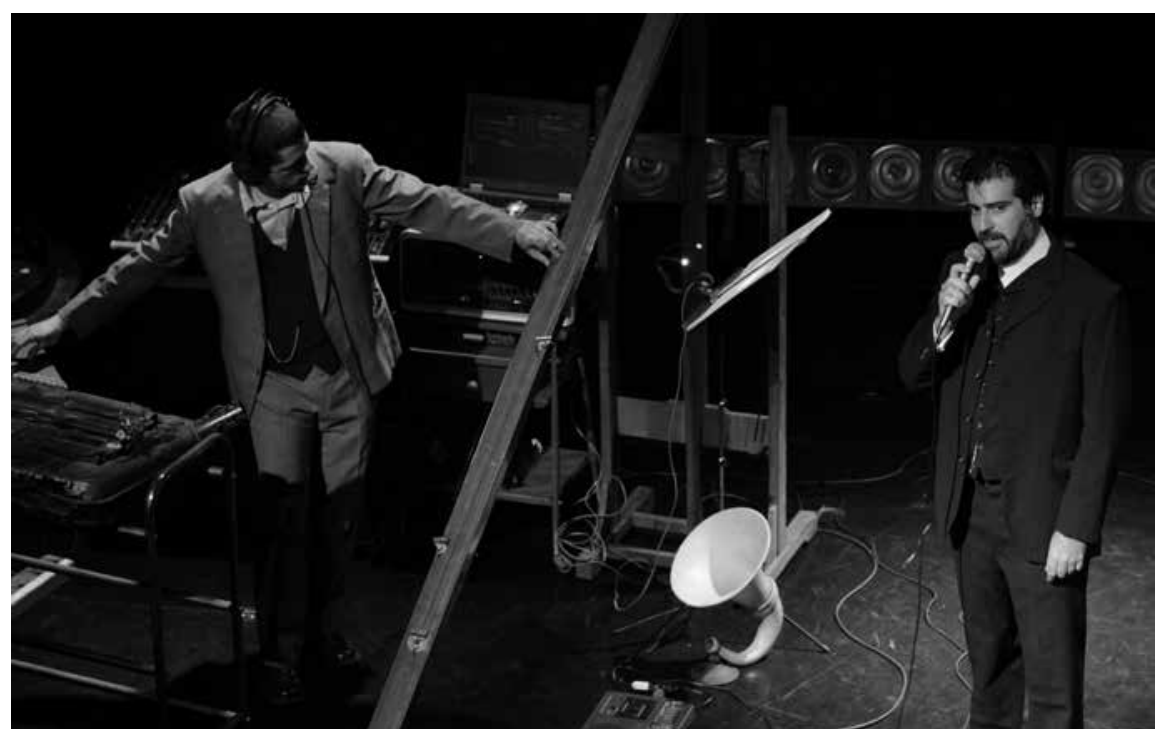

Figura 1. Rafael Spregelburd y Federico Zypce en escena de Apátrida. Doscientos años y unos meses. Foto: Ale Star.

El artículo fue publicado al año siguiente bajo el título "Cuando lluevan uvas" (66-75), en alusión a una de las notas periodísticas de 1891 que condenó la conversión de los pintores y críticos en duelistas, acertando a decir que "si cada polémica artística ha de hermanarse con personalismos incongruentes y resolverse a hachazos [...] ¡estamos frescos! Habrá arte y crítica artística en Buenos Aires, cuando lluevan uvas" ("Arte a sablazos"). Entre tanto, el "tramposo asunto del Bicentenario" - así definido por Spregelburd-propició que le comisionaran una obra para el ciclo Dramaturgias cruzadas del Instituto Goethe y Pro Helvetia, que convocaba a la escritura conjunta entre un autor suizo y otro argentino. Tras un intenso mes de julio escribiendo sobre aquella "anécdota fabulosa y material inspirador", las dos obras resultantes de este intercambio fueron presentadas como work in progress el 27 de agosto de 2010 en el auditorio del Goethe-Institut de Buenos Aires. Más tarde, Apátrida fue estrenada como obra exenta el 20 de marzo de 2011 en el teatro El Extranjero de la misma ciudad. ${ }^{4}$ Algunas de las filosas reflexiones que el dramaturgo había compuesto para la futura revista acerca

4 Es posible acceder al tráiler de la obra en https://www.youtube.com/watch?v=BT-eA7nD6qg 
de las posibilidades de la "argentinidad", de un arte nacional, de las condiciones de la crítica y la historia, pasaron a formar parte de los parlamentos de la obra. Una ficción que, sin duda, redobló la apuesta de la controversia histórica y llevó al extremo sus presupuestos. Spregelburd ha señalado su interés por representar la dicotomía, esa rivalidad constitutiva de la historia argentina:

Lo vemos claramente en nuestra actualidad política. La presentación de pares opuestos que por ser tan opuestos y tan radicales no llegan a síntesis alguna, por eso se perpetúan en el espacio como discusión y no generan ninguna superación de los términos iniciales de la discusión. [...] El teatro produce un grado muy curioso que es la constitución de una verdad que no es producto de cuál de las dos ideas triunfa, sino que es producto de la expectación del choque de las ideas. [...] Uno tiene la sensación potente de asistir a una especie de iluminación importante, después la obra termina y uno sigue sin saber por quién tomar partido. ("Sé lo que se dirá")

Esta idea se acentúa para el espectador de la obra por el efecto que produce en escena que el mismo actor - el multifacético Spregelburd- protagonice los dos personajes, las dos posturas que entre una y otra corrida hacia sus distintos atriles, sus distintos lugares de enunciación, sus trayectorias, sus rostros, sus principios se funden y confunden. Se fusionan en el mismo sujeto, en la mente del propio público-testigo de la contienda, viéndose en un espejo desdoblado como una radiografía de su "ser argentino", contrariado y revelado (figura 2). Al respecto, Luz Rodríguez Carranza sostiene:

[...] lo que tiene lugar en escena es una vacilación de la distancia crítica y que lo que se abre es un vacío insoportable, tanto para Auzón como para los espectadores. Como todas las obras de Spregelburd hay allí [...] un efecto político transitivo y no comunicativo ni contagioso. El espectador se ve confrontado a su propia ambigüedad entre la implicación y la distancia - porque las palabras producen las dos cosas simultáneamente.

Esta experiencia de expectación que propone el dramaturgo al encarnar a los pintores decimonónicos recuerda el "sutil sistema de esquivos" presente en la descripción que realiza Michel Foucault de la pintura Las meninas de Velázquez, ese tratado sobre la mirada que inicia su libro Las palabras y las cosas. Foucault sostiene allí que el pintor:

Fija un punto invisible, pero que nosotros, los espectadores, nos podemos asignar fácilmente ya que este punto somos nosotros mismos: nuestro cuerpo, nuestro rostro, nuestros ojos. Así, pues, el espectáculo que él contempla es dos 
veces invisible, porque no está representado en el espacio del cuadro y porque se sitúa justo en este punto ciego, en este recuadro esencial en el que nuestra mirada se sustrae a nosotros mismos en el momento que la vemos. (14)

Ese sistema de esquivos reflejos entre la representación y lo representado, entre el afuera y el adentro del campo de representación, dispara la deriva del pensamiento sobre el lugar que ocupamos.

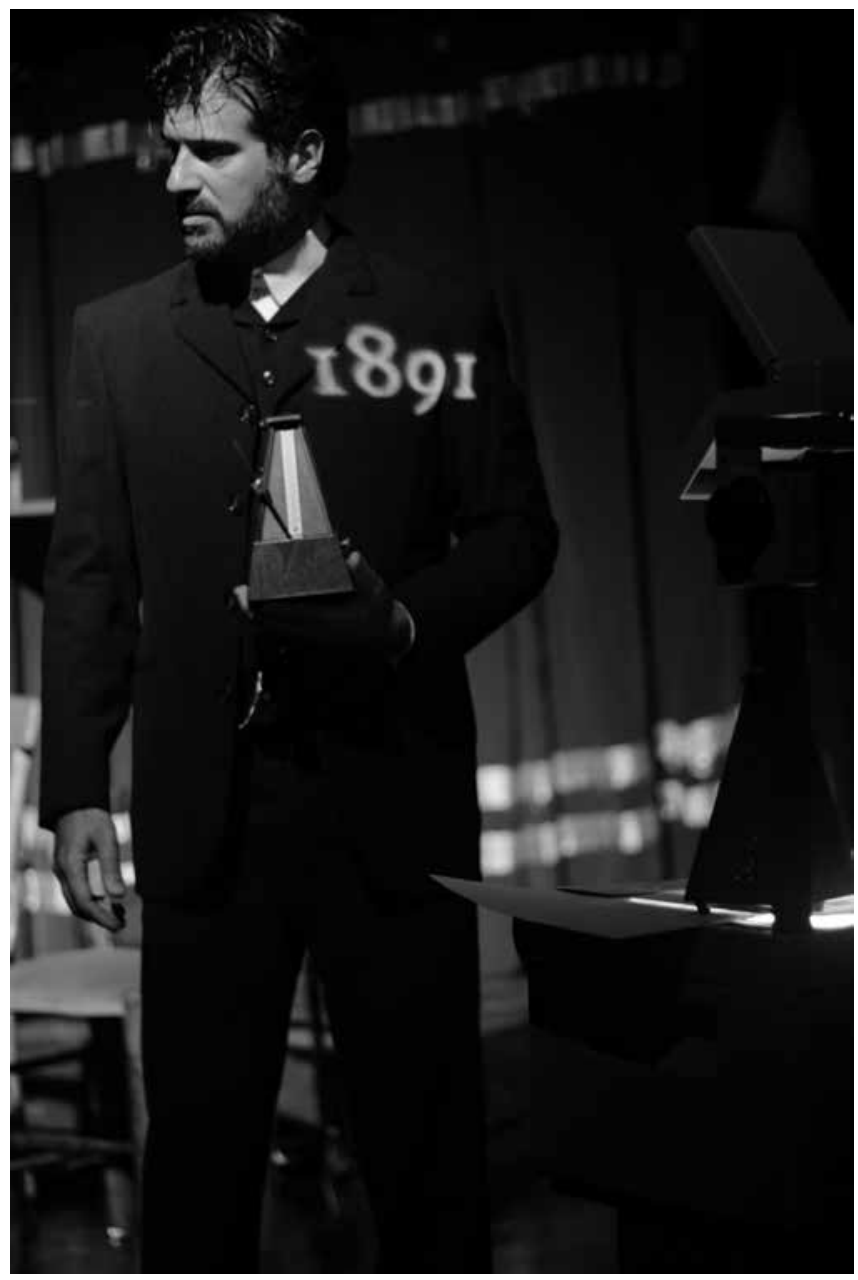

Figura 2. Rafael Spregelburd en escena de Apátrida. Doscientos años y unos meses. Foto: Ale Star. 


\section{Escena cuatro. Historia y ficción}

Aquellos debates del siglo XIX, redimensionados por una obra artística contemporánea, cobraron un interés excepcional tanto en el ámbito artístico como en el académico, dentro de Argentina y fuera de esta. Un aluvión de escritura de reseñas periodísticas y artículos críticos sobre la obra ha ocupado las columnas sobre artes escénicas y artes visuales en diferentes diarios, revistas culturales y blogs. ${ }^{5} \mathrm{Al}$ cabo de poco tiempo se redactaron papers y se presentaron ponencias en encuentros académicos nacionales e internacionales que analizaron diferentes aspectos de aquel hecho teatral y su publicación. Este fenómeno trajo como consecuencia otro que cobra una particular significación para uno de los protagonistas de la controversia. Max Eugenio Auzón, como hemos visto, sepultado en el pasado -si se lo compara con la suerte de su contrincante Schiaffinotuvo una secular resurrección y gloria. Una resurrección, dado que su nombre y pensamiento resurgió de manos de la práctica de la disciplina histórica, cuando su cuerpo textual se exhumó de los archivos, para luego habilitar su gloria tras el suceso artístico que lo reencarnó sobre las tablas y le dio una trascendencia inusitada. De ahí que Auzón es hoy menos personaje histórico que figura ficcional. Si nos detenemos un minuto en ese oráculo contemporáneo que es Google, comprobaremos que las entradas del Auzón-Ápatrida existen en una proporción exageradamente mayor que las del A.Zul de Prusia original.

En la ficción, el héroe extranjero es reinventado como un sujeto histórico que se separa de la élite de la Generación del 80 a la cual Auzón definitivamente supo pertenecer. Sus justicieros parlamentos que denuncian el genocidio sobre el que se construyó el Estado nacional argentino: "Somos el triunfo de un discreto genocidio. / Hemos abierto el camino al sur / a fuerza de aguardiente / Hemos emborrachado al indio hasta matarlo", dice el personaje en el desolador monólogo final, en huida tras haber herido al contrincante. Lejos de haber padecido un nuevo destierro, el Auzón histórico fue secretario de la Dirección de Territorios. Sin duda, si se piensa en las implicancias del reparto territorial por entonces (y ahora), la empatía con el atormentado personaje se desvanece. Recordemos aquí su comentario cínico, a la vez que elogioso, para con la gran pintura de Ángel Della Valle, La vuelta del malón (1892), meses más tarde del duelo y mucho años antes de que fuera considerada una de las obras canónicas del arte argentino del siglo XIX (figura 3). Una obra que, sin duda, sintetiza los temas que "justificaron la campaña

5 El interés perdura y se revitaliza actualmente con el reestreno de la obra en Buenos Aires en marzo de 2016. Como ejemplo, véase la reciente producción del podcast "Un imaginario para la Nación Argentina", en: http://proa.org/esp/proa-radio.php 
del desierto" (Malosetti Costa) comandada por el general Julio Argentino Roca y por extensión la colonización de América. Escribió A.Zul de Prusia:

El Pampero soplará mientras haya atmósfera en torno al planeta, pero los indios no siempre podrán arrasar, robar, incendiar y violar, porque los indios van tomando el mismo camino que los dioses quienes han desaparecido, corridos por el desprecio del público, cansado este de verles arrasar, robar, incendiar y violar - exactamente las mismas fechorías que cometen los indios, lo cual dejaría, sea dicho de paso, suponer que los dioses no fueron jamás otra cosa sino indios disfrazados bajo la conducta del libertino cacique Zeus. Es evidente que la completa desaparición de la raza roja es solo cuestión de años, y en tal caso es necesario apresurarse si se quieren estampar sus rasgos con los contornos muy marcados que la hicieron resaltar, malogrado su inferioridad cerebral. ("Bellas artes" 1 )

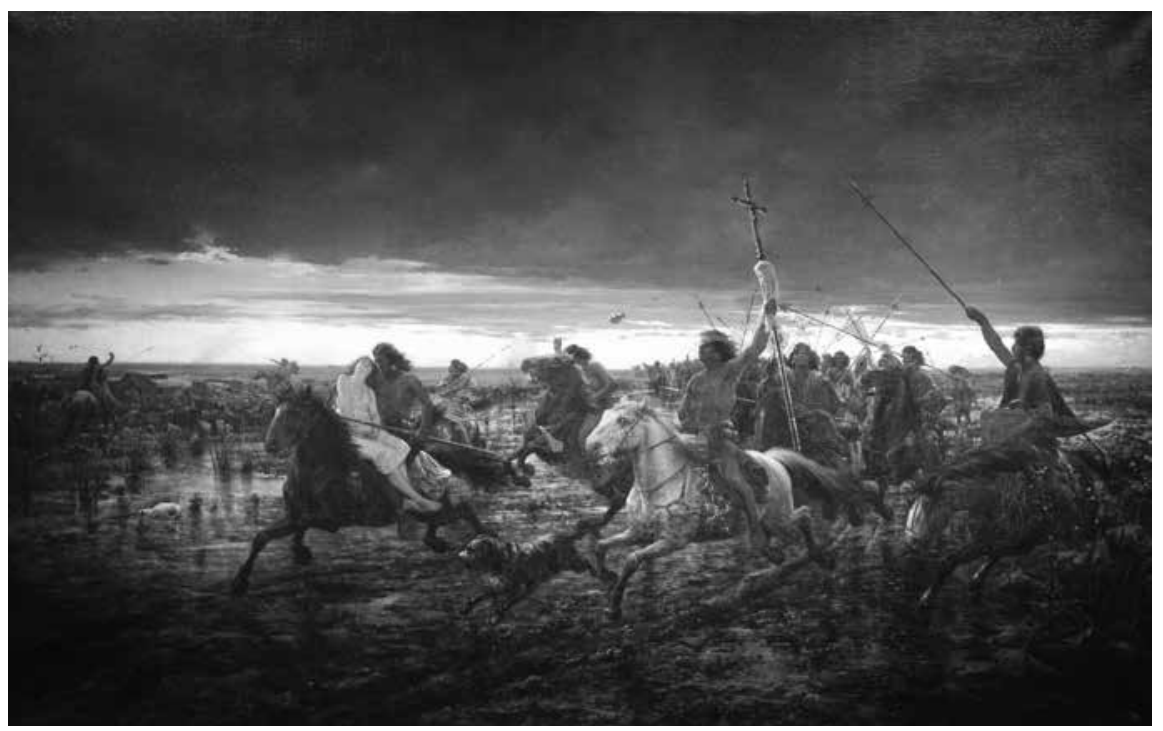

Figura 3. Ángel Della Valle, La vuelta del malón, 1892, óleo sobre tela, 186,5 × 292 cm. Colección Museo Nacional de Bellas Artes, Argentina.

Las incongruencias entre los personajes históricos y ficcionales son varias pero, paradójicamente, estas nuevas entidades logran reproducir y representar la actualidad de sus controvertidas sentencias en las arenas políticas presentes, donde es posible reconocer deambulando a sus alter ego contemporáneos. 


\section{Escena cinco. De retratos y apropiaciones: "A mí me gusta acá"}

Entre las diversas entrevistas a las que Rafael Spregelburd fue convocado a instancias del estreno de Apátrida, una de ellas, producida por la revista de arte Sauna. Espacio de Pensamiento a $110^{\circ} \mathrm{C}$, dio origen a una serie de retratos realizados por el fotógrafo Marcos López (Santa Fe, 1958). En las sesiones de trabajo propuestas por este último, el actor protagonizó la recreación de célebres pinturas de David Hockney y fotografías de Jeff Wall. La portada de la revista digital ${ }^{6}$ y la entrevista fueron ilustradas con una composición de aquellas imágenes y con el backstage de la producción fotográfica (figura 4). Los retratos de Spregelburd fueron incluidos allí junto a otras obras recientes de Marcos López, encabezadas por un breve texto suyo donde afirma: "A mí me gusta acá. Fotografiar lo que está cerca. Pintar mi aldea y ser universal". Este asunto ha sido recurrente en la producción del fotógrafo y parece saldar el dilema del ser nacional o pertenecer al mundo o, al menos, sumar ensayos sobre la identidad del arte producido en estas latitudes y de reconocimiento internacional. ${ }^{7}$ En este sentido, recordemos las series del fotógrafo santafesino como Pop Latino, Sub-realismo criollo, ;Ay!... Patria mía, Vuelo de cabotaje que construyen su poética en los cruces del llano costumbrismo y la sofisticación de los códigos de la publicidad; en el tránsito irreverente de la "retórica localista latinoamericana y el modelo clásico del retrato" (González 108).

Algo de esta irreverencia en la conjugación de materiales "nobles" y "populares" sintoniza con las poéticas de Spregelburd y de Zypce enlazadas en la puesta en escena de Apátrida y acentuadas en el desconcertante baile final al ritmo de un hit musical de verano (figura 5). La interpretación de los llamamientos de Schiaffino, impostada en un megáfono de plástico a escala irrisoria; la erudita musicalidad de las cuerdas con el rodar de bolitas de vidrio sobre chapones de carrocerías; el canto lírico con el remixado de cumbia; la pretendida distinción cultural, sellada al vacío con la cortina musical de un programa de televisión de la conductora Mirtha Legrand. Spregelburd afirma que el pop:

6 http://www.revistasauna.com.ar/01_09/tapa.html

7 Cabe referir aquí que la primera oración mencionada - presente en otros textos de Lópezremite directamente a las sentencias de otro artista y performer argentino, Federico Peralta Ramos, que a comienzos de la década de los setenta solía recitar su célebre poema que versa: "No quiero ir a la Luna / A mí me gusta acá / A mí me gusta acá / A mí me gusta acá. / Quiero caminar por las calles de Buenos Aires / A mí me gusta acá / a mí me gusta acá / a mí me gusta acá. / Me quiero sacar una foto en la plaza San Martín / a mí me gusta acá. / Quiero ser amigo del obelisco / a mí me gusta acá. / Me encanta el atardecer en el campo argentino / a mí me gusta acá / a mí me gusta acá / a mí me gusta acá". 
[...] produce por un lado una rara felicidad en la contemplación y al mismo tiempo no anula las preguntas importantes. Que no son las preguntas sobre el destino del arte si no las preguntas por la vida de las personas. Y como somos una sociedad híbrida, mestiza y demás, tenemos una relación con lo pop que es natural. En las culturas europeas donde hay tradiciones fuertes debe ser más difícil. Nosotros no tenemos el peso de esa tradición shakespereana o de Schiller o de Goethe, entonces no sentimos que nuestro hacer sea la continuidad y que se va a morir si nosotros no la sostenemos. No somos los adalides de esa batalla. En ese sentido es casi imposible no ser pop en este país. ("Sé lo que se dirá")

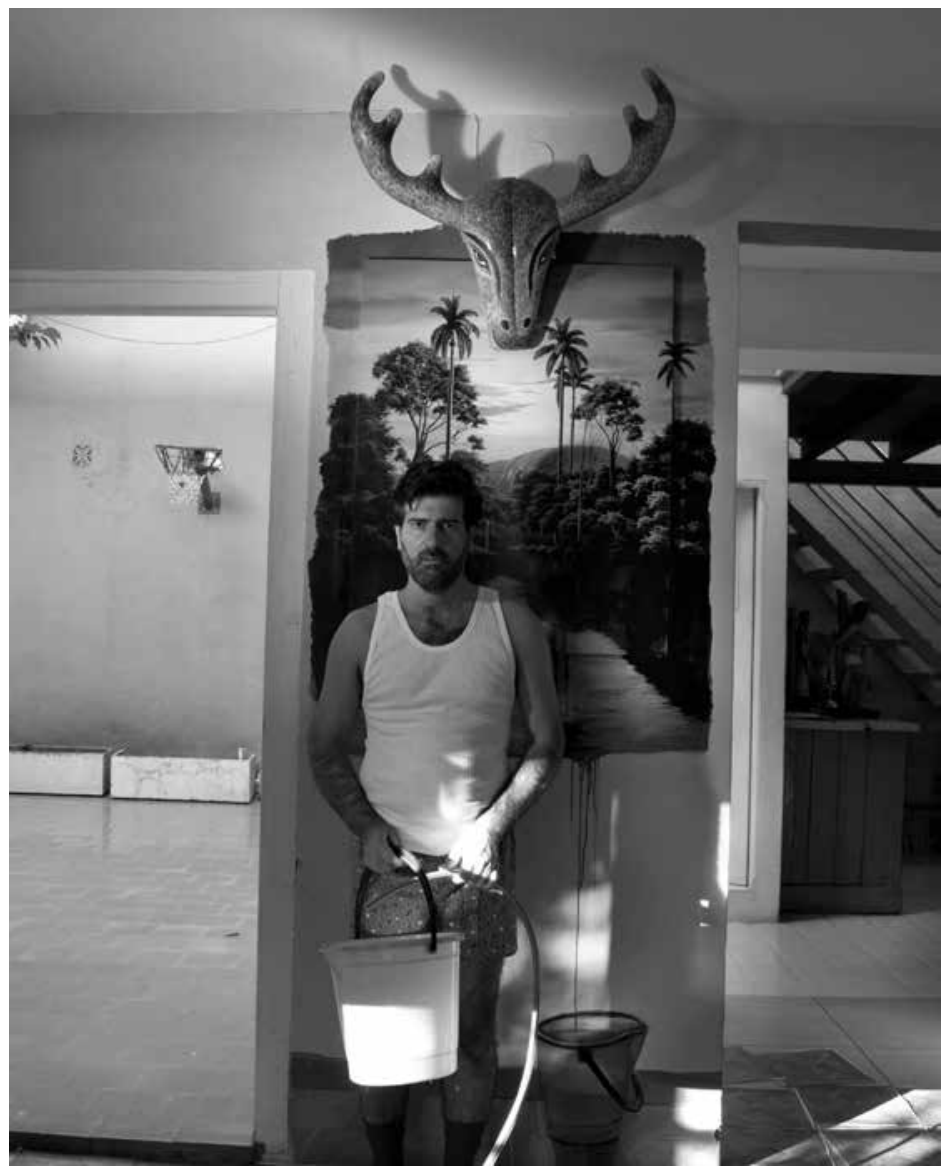

Figura 4. Marcos López, Hombre y alce. Buenos Aires, 2012. 


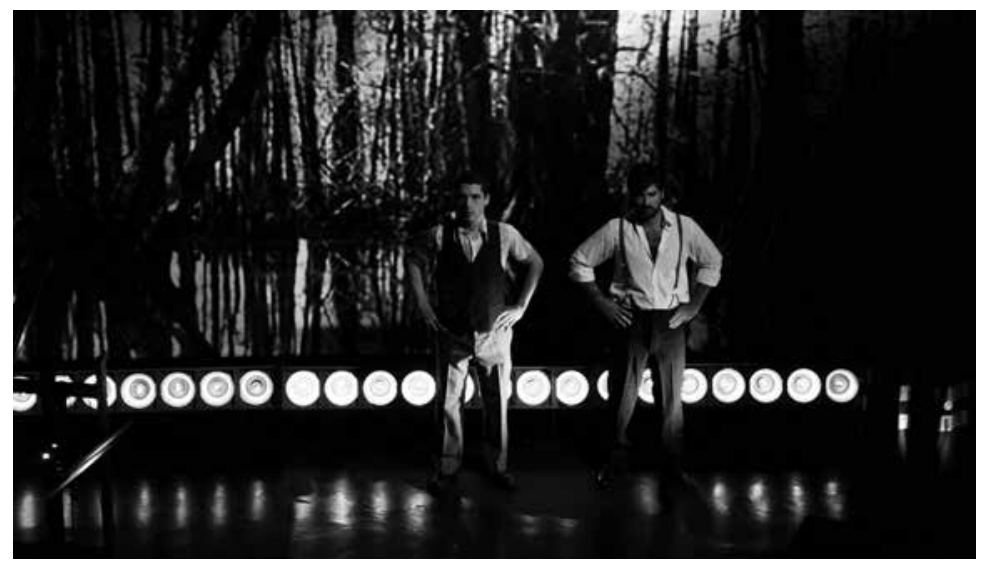

Figura 5. Marcos López, Hombre que cae. Buenos Aires, 2012.

No parece casual que Marcos López haya elegido apropiarse de la pintura pop de David Hockney, Portrait of an Artist (Pool with Two figures), de 1971, para retratar al actor como un doble contrariado, doppelgänger, uno con traje decimonónico y el otro en pijama (figuras 6 y 7). El modelo estalla en un telón de fondo. Ya no es el umbral de la piscina impoluta de las mansiones de Beverly Hills, es en todo caso la Pelopincho llenada a manguera y balde. Ya no es el liso cielo californiano el que recortan las colinas, sino el mantel de hule estampado y saturado de rosas rococó rosadas como último signo de nuestra naturaleza cultural. Las transposiciones del lenguaje pictórico y fotográfico se exacerban en el retrato de Spregelburd como el protagonista de Milk (1984), de Jeff Wall — considerado uno de los iniciadores de la staged photography-. Una ardua recreación de un instante fugaz sobrepuesto a la apropiación de la fotografía original pintada. Una vez más se duplica la imagen del actor que pasa a ocupar el lugar del personaje de Wall, una suerte de paria social, desafortunado, que genera un caos contenido sobre el orden reticular establecido por los ladrillos del fondo.

El encuentro entre el dramaturgo y el fotógrafo derivó, a su vez, en la realización de un audiovisual dirigido por López, donde Spregelburd encarnó nuevamente al personaje del crítico Schiaffino/Auzón para vociferar duros juicios sobre las obras exhibidas en su muestra realizada en la sala Cronopios del Centro Cultural Recoleta de la ciudad de Buenos Aires, en 2013. Allí se exhibieron los retratos mencionados como fotomontajes de grandes imágenes reproducidas y superpuestas. López guionó al actor quien, subido a un banquito, desplegó una suerte de visita guiada a modo de sermón frente a un grupo de actores - que también intervinoentremezclados con el público (figura 8). Sus parlamentos componían un collage de 
los temas recurrentes del episodio original del siglo XIX, con sentencias similares a las escuchadas en Apátrida, junto a definiciones del ser crítico y apreciaciones severas sobre la producción del artista visual, en las que se interceptaron referencias a citas de críticas publicadas contemporáneamente a la muestra. El crítico de la performance, indignado ante la producción del artista explica:

En realidad, lo que yo hago, es tratar de traducir a un lenguaje más simple, descifrar los códigos con los que el artista está hablando. Algo así como lo que llamaban El Lenguaraz, en la época de la Campaña del desierto. El Lenguaraz era el indio que hablaba también la lengua del amo. De los amos, de los dueños de la tierra, del gobierno,y del ejército, que dicho sea de paso, están todos enterrados aquíal lado. En el cementerio de la Recoleta. [...] Bipolaridad. Esquizofrenia. Ingenio. Cita. Remake. Subtextos. Guiños. Copia de la copia [...] Además, ustedes creen que a alguien le importe todo esto, que a los que tienen las decisiones de convalidación artística en el mundo, le interese este eclecticismo estilístico producto del nieto de inmigrantes de un país que navega en la insensatez...? [...] No inventó nada: está bien, convengamos que en el arte contemporáneo no es necesario inventar nada... pero por lo menos que lo pinte él... con sus propias manos.

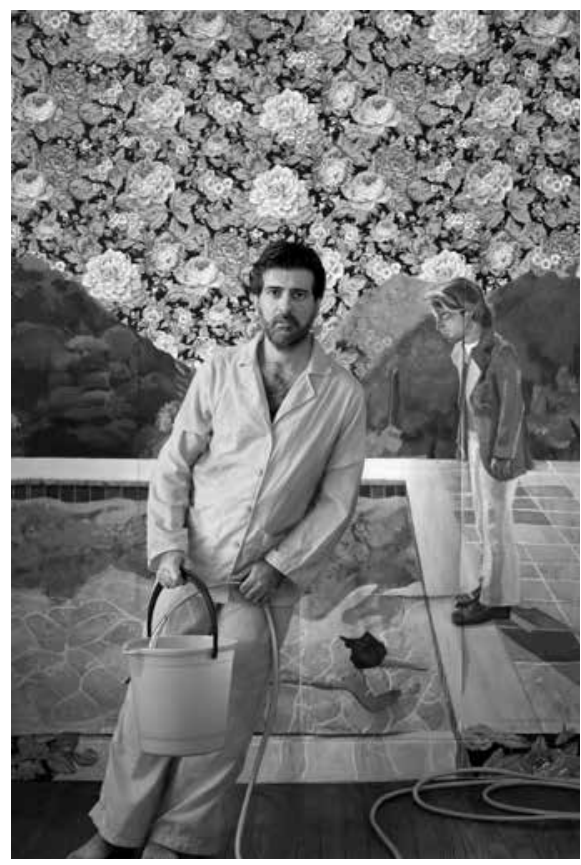

Figura 6. Marcos López, Hombre en traje. Buenos Aires, 2012. 
Estados del arte. Puestas en escena de construcciones históricas e imaginarias durante el Bicentenario en Argentina

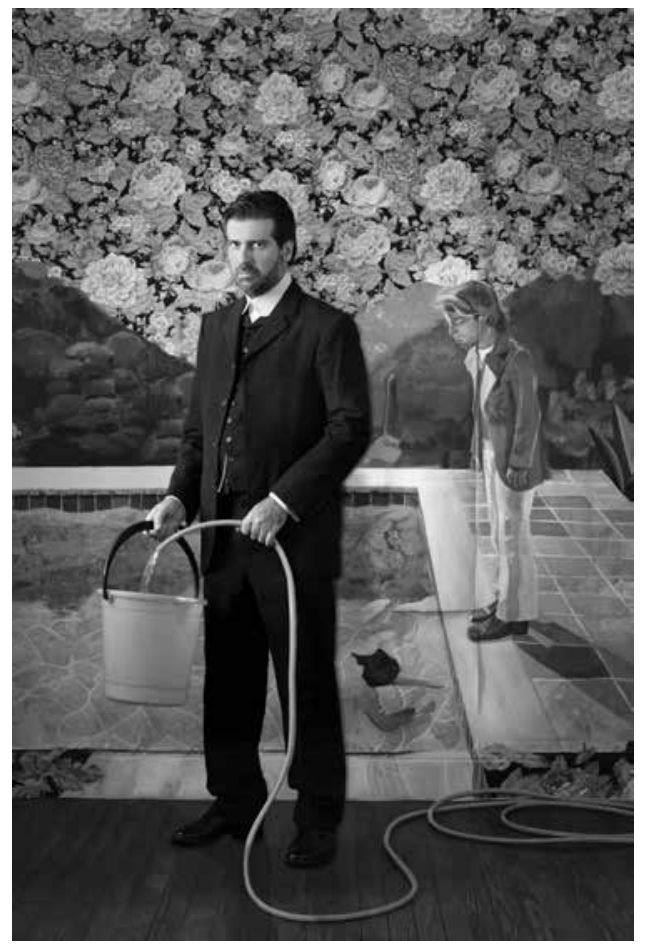

Figura 7. Marcos López, Hombre en traje. Buenos Aires, 2012.

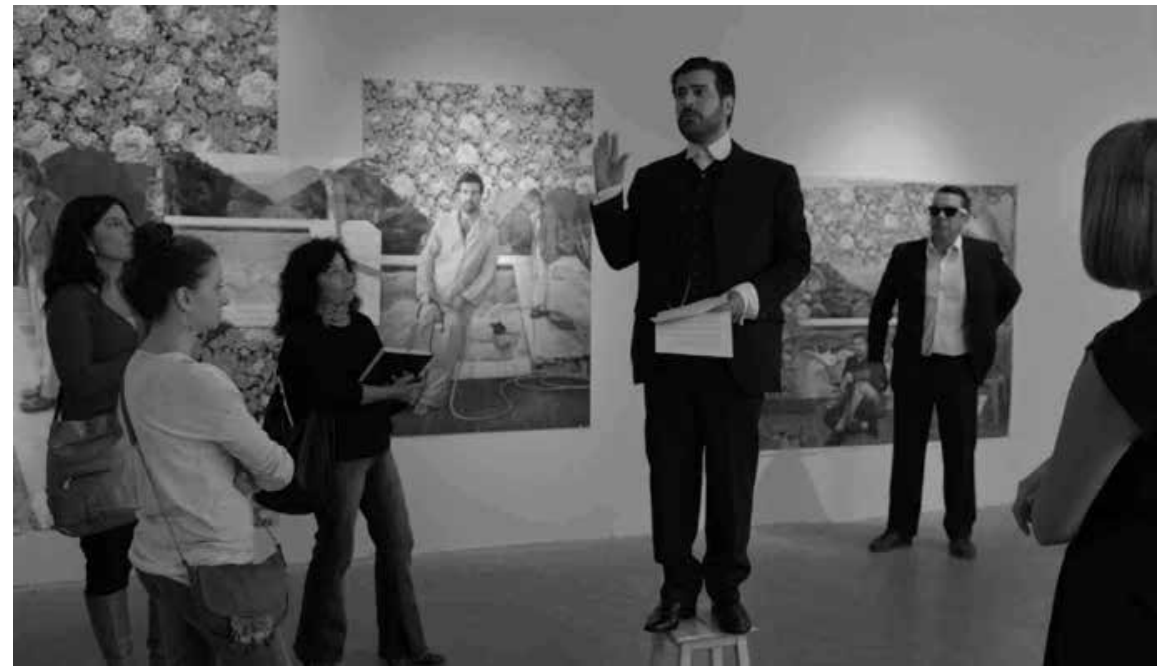

Figura 8. Marcos López, Rafael en sala Cronopios. Buenos Aires, 2013. 
El interlocutor culminaba esta especie de autoacusación de López sobre la autoría de la obra, pintada por sus asistentes, con una denuncia que vinculaba una vez más las relaciones entre arte y Estado: "Y a esta sala la estamos pagando todos con nuestros impuestos. Sinceramente, después del ready made se fue todo al carajo". De alguna manera, esta nueva puesta en escena operó a su vez como un corrosivo autorretrato del artista santafesino. Y las derivas de sus apropiaciones fotográficas, pictóricas y literarias continuaron como subproductos en diferentes montajes. El audiovisual filmado por López formó parte de una instalación en la feria arteBA del mismo año, donde en una casita montaron nuevamente algunas de las obras exhibidas, como los retratos de Spregelburd.

\section{Escena seis. Un torneo de esgrima verbal}

Inspirada en el episodio del duelo, recargado en Apátrida, la artista Marcela Sinclair (Buenos Aires, 1968) organizó la cuarta edición de su Nueva Socioensayística Micromodélica $\left(\mathrm{NSM}_{4}\right)$, un proyecto que consta de una serie de encuentros en los que representantes del campo de la cultura comparten una actividad en un contexto de sociabilidad inhabitual (Sinclair). Se trata de reuniones, tipo tertulias semiabiertas, que buscan alejarse de los formatos habituales de producción y exhibición de las artes y conservan cierta intimidad para alentar modos diferentes de diálogo y pensamiento. En septiembre de 2012, con la colaboración del crítico y curador Javier Villa, Sinclair convocó a un grupo de invitados vinculados al circuito de las artes visuales a participar de un torneo argumentativo llamado Te bato a duelo y llevado a cabo en la Sala de Armas del Club de Gimnasia y Esgrima de Buenos Aires (figura 9). Asistieron como invitados el juez y coleccionista Gustavo Bruzzone, la actriz Vivi Tellas y el sociólogo Lucas Rubinich, quienes actuaron como jueces de las contiendas que proponía el encuentro. Participaron: la socióloga y artista Mariana Cerviño, el periodista Marcelo Dansey, el filósofo José Fernández Vega, la galerista Nora Fisch, el artista Patricio Larrambebere, la gestora cultural Solana Molina Viamonte, el historiador del arte y artista Santiago Villanueva, el editor Teo Wainfred y quien escribe. Durante una extensa jornada se llevaron a cabo duelos argumentativos entre duplas de invitados sobre frases preestablecidas acerca de temas como los artistas, los museos, los críticos, la historia del arte y el mercado, entre otros asuntos sobre los que aquellos históricos artistas-críticos de 1891 y sus dobles personificados en la ficción teatral de Apátrida en 2010 supieron discutir severamente.

Al llegar a la sala de armas, los participantes recibían un blasón (en rigor, un escudo en forma de prendedor) que los identificaría y que servirían para sortear la organización de los asaltos. Enfrentados en mesas, cronometrados y observados 
por jueces, los duelistas debían establecer un desacuerdo sobre la lectura de ciertas afirmaciones escritas por los autores del encuentro llamadas tarjetas batidoras. Frases de muy diversa índole que de alguna manera funcionaban como síntesis de ciertos supuestos y concepciones del arte circulantes y que invitaban a tomar partido, por ejemplo: "Sin un patriciado educado, no puede haber buen arte en un país"; "En nuestro medio no hay crítica de arte"; "El arte contemporáneo es una gran farsa"; "El arte erudito es masturbatorio y no se anima a encarnar relaciones íntimas con la sociedad por miedo a la impotencia"; "No hay que subestimar al espectador y forzar su acceso, el arte es una especialidad como la medicina o el automovilismo"; "Ser marginal ya no es más ser un héroe"; "El debate entre una obra formal y una obra política que dominó el siglo XX en la Argentina, desde Florida y Boedo hasta light y Luxemburgo, ha llegado a su fin"; "Los artistas son cada vez más conscientes de su potencial entrada en la historia y producen obra pensando en ello"; "El mercado del arte escribe la historia del arte", entre varias proposiciones. Los duelistas se iban eliminando unos a otros siguiendo un organigrama establecido, los perdedores pasaban a ser padrinos-consejeros de los participantes que seguían en carrera en el torneo hasta que en el último duelo salió ganador el periodista y crítico Marcelo Dansey, que es también uno de los editores de la revista Sauna, que mencioné en el apartado anterior (figura 10).

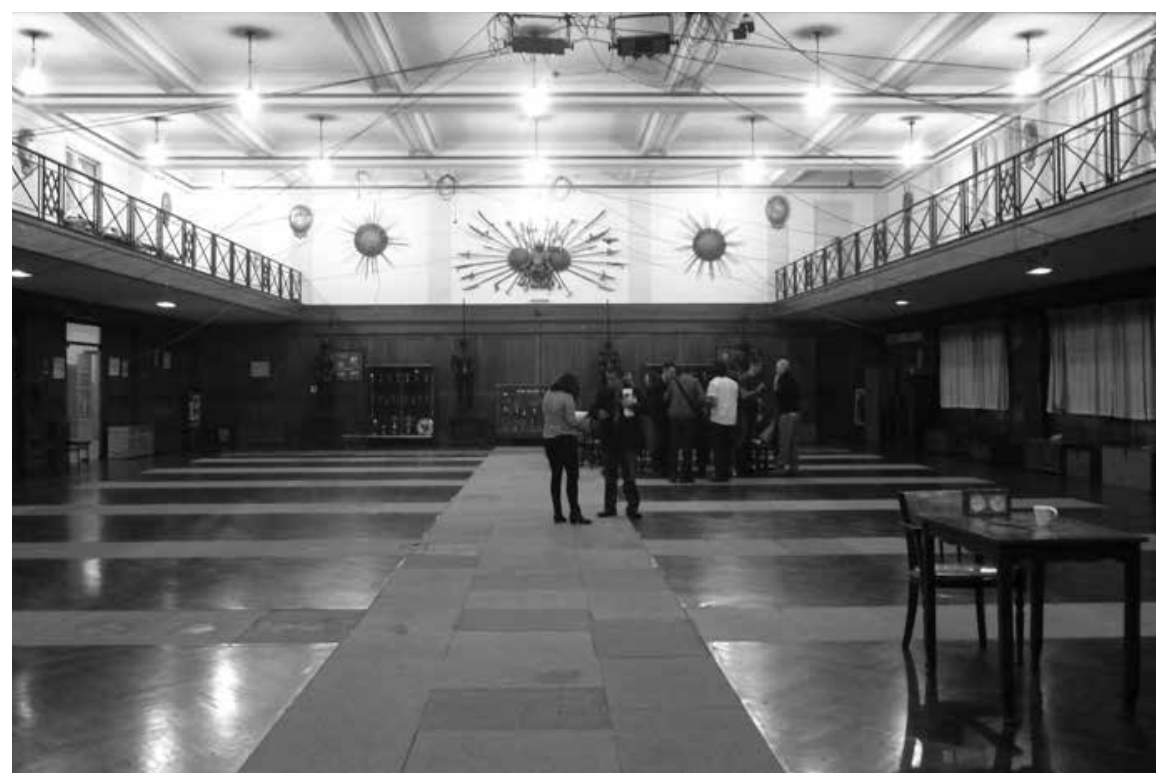

Figura 9. Marcela Sinclair, Nueva Socioensayística Micromodélica \#4, 2012. Vista de la Sala de Armas del Club de Gimnasia y Esgrima de Buenos Aires donde tuvo lugar el Torneo de Debates. 


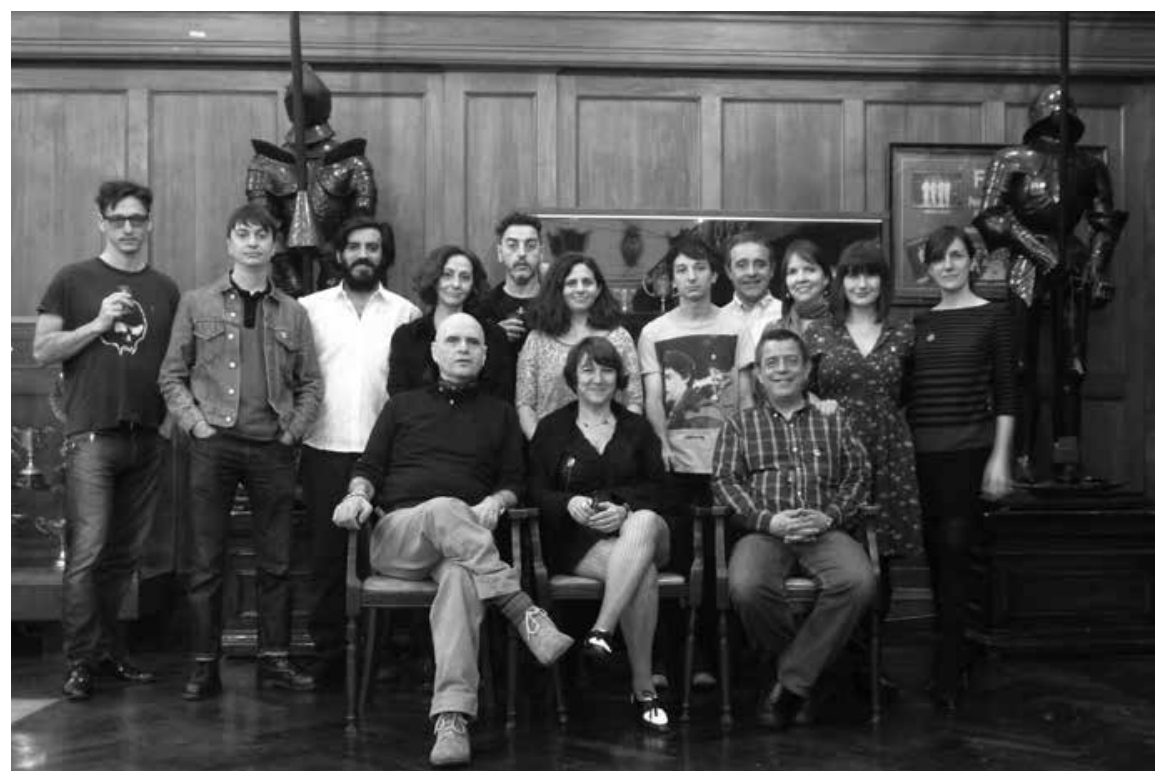

Figura 10. Marcela Sinclair, Nueva Socioensayística Micromodélica \#4, 2012. Participantes del Torneo de Debates en la Sala de Armas del Club de Gimnasia y Esgrima de Buenos Aires.

$\mathrm{La} \mathrm{NSM}_{4}$, "obra" de Sinclair, fue documentada por algunos pocos registros fotográficos y textuales escritos por dos de los "observadores participantes de Identidad Reservada" - así los llamó la creadora- que analizaron la experiencia a posteriori. Se publicaron como fanzines dos textos: "Vitalidad cultural en la sala de armas", de Lucas Rubinich y "Críticas y sentencias extemporáneas", de Santiago Villanueva, fueron leídos en otros encuentros para un público más amplio. Villanueva, sin aludir al evento, desarrolla en su texto una breve disquisición sobre el ejercicio de la crítica que cree no existe en el medio actual, para lo cual retoma ciertos escritos de críticos argentinos de las primeras décadas del siglo XX como Julio Rinaldini y Romualdo Brughetti. Como parte de su propia práctica artística, el joven artista trabaja precisamente sobre los materiales y fuentes de la historia del arte y de la crítica argentina, produciendo una suerte de "arte historiográfico" que se enlaza con la "pulsión de archivo", tan desarrollada en el arte contemporáneo (Foster, "An Archival"; "Archivos").

Para uno de sus proyectos artísticos Villanueva (Azul, 1990) ha reeditado un facsímil del texto de la conferencia del escritor, pintor y crítico José León Pagano, dictada en Amigos del Arte, en 1926: "El nacionalismo en el arte". Esta publicación formó parte de su muestra 1931, llevada a cabo en Abate Galería en Buenos Aires, en junio de 2012, que culminó asimismo con la lectura de la mencionada 
conferencia por el historiador del arte Roberto Amigo, que finalizaba diciendo: "Así la quiero porque así es esta tierra mía, consciente de su destino, afortunada conjunción de energías fecundas, abierta a los cuatro vientos. Así la quiero porque así como es, realiza en la historia una misión de cultura que, siendo muy argentina, es también universal". En aquella sala, Villanueva había dispuesto paneles con reproducciones de imágenes y documentos visuales y textuales de la historia del arte argentino (figuras 11 y 12). En aquella instalación seudomuseística, el artista se apropiaba del dispositivo mentado por Aby Warburg en su Atlas Mnemosyne para experimentar la reescritura de la historia local. Más recientemente realizó la exposición Pagano. El arte como valor histórico, en La Ene, espacio fundado y autodefinido como Museo Energía de Arte Contemporáneo. Dedicó la muestra a revisar la figura de quien considera opacado e invisibilizado: "un pensador incansable que recurrió a la acción cuando creyó necesario: fue conferencista en numerosas ocasiones, fue pintor cuando no comprendió los avatares técnicos de la disciplina, fue dramaturgo y ensayista, novelista y esteta" (Villanueva 2).

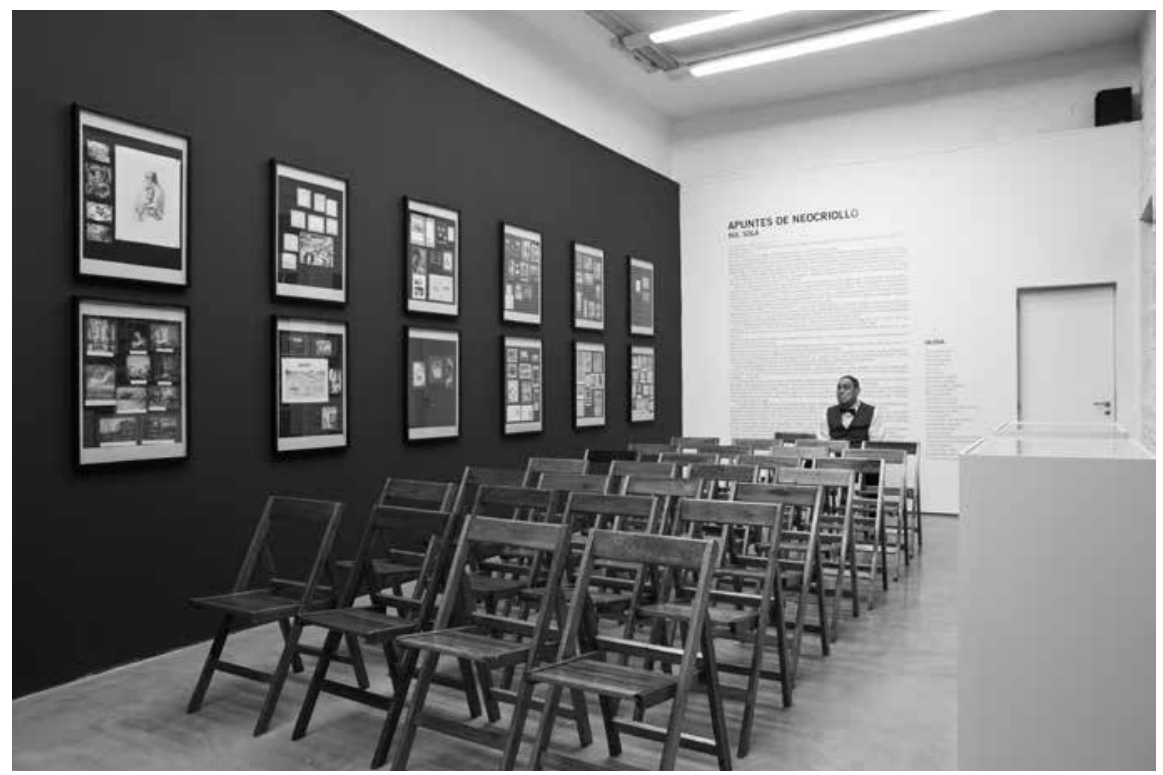

Figura 11. Santiago Villanueva, Vista de la exposición 1931, Abate Galería, 2012.

El escrito de Villanueva para la $\mathrm{NSM}_{4}$, atravesado por cierta nostalgia presente en su pluma y algo embebido en la retórica de los críticos que son su materia de estudio e investigación, clama por que la argumentación no sea solo un 
ejercicio crítico, sino de acción. Algo sobre lo que justamente la NSM4 de Sinclair busca experimentar en situaciones site specific.

Por otra parte, en su texto-registro Lucas Rubinich señaló los méritos de la "obra-acontecimiento" de Sinclair por reinstalar la práctica de la argumentación por fuera de tres tipos de discursos públicos vigentes. En primer lugar, señala que lo sucedido en la $\mathrm{NSM}_{4}$ se apartó del discurso con "vocación trascendente que tuvo fuerza en otro momento histórico" - como el vivido por Schiaffino y Auzón, agrego por mi parte- y que a menudo "se usa como recurso a mano en un mundo que es otro". En segundo lugar, lo dicho se distanció del discurso técnico-académico que, según el sociólogo, a menudo responde menos a una forma intelectual que a una burocrática. Por último, desde su perspectiva aquella experiencia se alejó del discurso frecuentemente articulado por los artistas, "como parte de su nuevo rol de empresario de sí mismo, incorporando reglas y lenguaje estabilizados por el mundo internacional".

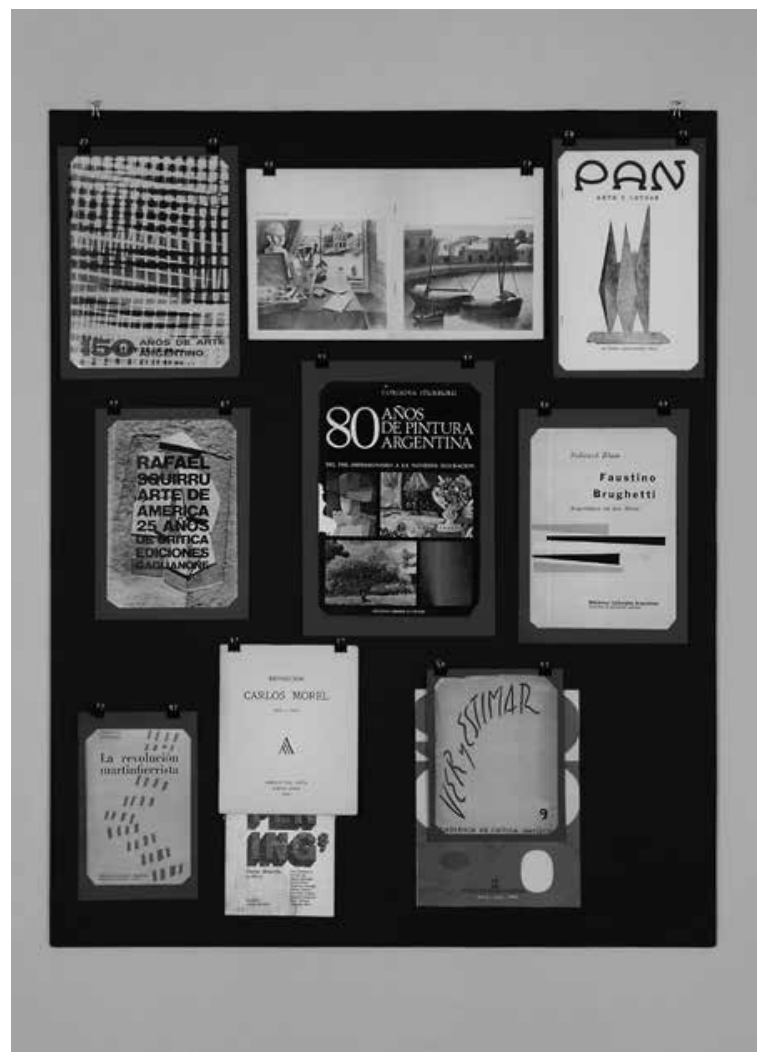

Figura 12. Santiago Villanueva, Panel 10, $70 \times 50 \mathrm{~cm}$., fotografía, 2012. 
En definitiva, se trata de inventar condiciones para poner en acto el juego de la argumentación, fuera de la cristalización de esas formas de discurso y "del uso instrumental de recursos para fines específicos [que] es uno de los fantasmas que recorren el presente". Con el propósito de superar la pura autoridad cultural:

[...] la lucha contra la cristalización, contra la cosificación de los discursos sean estos nostálgicos o fetiches novedosos, es una lucha con una impronta libertaria, más allá de que no existan banderas de lo nuevo. Es creadora no por anunciadora de una nueva era sino por problematizar la alienación en el mundo del presente. Y hay quizás en estos momentos algo de relajamiento, de expresiones con formas del cinismo que no necesariamente portan una identidad dramática y hasta pueden ser alegres. [...] Y es entonces este clima el que permite desprenderse de mochilas culturales prestigiosas que tienen, y seguramente tuvieron, también valor opresivo. (Rubinich s. p.)

Y concluye, "la argumentación en debate y en contexto de grupo, siempre tiene algo que permite escaparse, aunque sea un poco, de lo que simplemente hay que decir" (Rubinich). Si bien es siempre difícil medir la inscripción social efectiva de experiencias como estas, más aún si se la considera tal como ha sido definida por su mentora como un "proyecto excéntrico de reconcentración endogámica", cabe pensar que la sumatoria de todas ellas, la reflexión sobre todas ellas, ayuda a poner en el ruedo, en diferentes registros y escenarios, imágenes que interpelan el régimen estético contemporáneo.

\section{Puesta en escena-puesta en abismo}

Ya nadie es lo que era en las arenas descompartimentadas de la artes. Un actor, dramaturgo y director (Spregelburd) luce como historiador irreverente; un compositor musical y luthier industrial (Zypce) es un Df-performer que ecualiza el sonido de los tiempos; un fotógrafo y pintor (López) es guionista y director de retratos fijos y cuadros en movimiento; una artista plástica (Sinclair) es socióloga experimental; otro artista, historiador y curador (Villanueva) es un editor revisionista compulsivo. En sintonía con las transformaciones en los estados expandidos del arte, la serie de imágenes visuales, textuales, sonoras y audiovisuales que aquí enhebro se salen de la normatividad reinante - en particular durante la reciente celebración del Bicentenario en Argentina - para cuestionar ciertos supuestos, para suspender los juicios dogmáticos y reelaborar las preguntas siempre necesarias. Estas experiencias ensayan respuestas abiertas, incompletas y hasta equívocas que, sin embargo, revelan tanto los estados en desagregación del propio arte como los intentos por construir un Estado argentino verosímil, concebido también 
como "la historia de sus ficciones, la suma de sus imágenes". Es en la cualidad disruptiva de estas prácticas donde operan sus efectos de fortalecimiento del disenso en el orden determinado. Son "creaciones disensuales" - podríamos decir en palabras de Rancière- porque introducen un material incongruente, una contradicción, un pleito que se opone a la configuración del consenso inhibidor que activa la despolitización de las comunidades, en este caso, de una comunidad imaginada por artistas e historiadores doscientos años y unos meses después de la Revolución de Mayo de 1810. El duelo y las alegorías del duelo anclan esta suerte de puesta en abismo artística de la historia. Una puesta en abismo de la cual este mismo artículo forma parte como marco o encuadre provisorio de toda una serie de imágenes sucesivas en las que resuena aquella remota escena decimonónica. Entre tanto, el tema ya tradicional del artista en pugna con el crítico pierde vigencia si se entiende el ejercicio de la crítica como parte de las tareas de interpretación propias del investigador e historiador de la cultura. Donde primaba la rivalidad, se instala una complicidad creativa. Donde se consagraba la asepsia del saber, por un lado, y un antintelectualismo, por el otro, donde se enaltecía la división entre práctica y teoría, se favorece la construcción conjunta de conocimientos sensibles sobre el pasado y el presente.

La historia del arte es tema y materia de las obras analizadas. Como disciplina ecfrástica que se construye desde la escritura sobre la imagen a la vez que puede basarse en los escritos acerca de las imágenes (fuentes documentales) ha tenido un desarrollo inédito y acelerado en las últimas décadas en la Argentina y Latinoamérica. En consecuencia, ha ampliado sus espacios de inscripción más allá de la historización canónica de las consideradas bellas artes; se ha nutrido al tiempo que nutre el cruce con otras disciplinas sociales y humanísticas; ha redefinido sus campos de acción desde la academia a las instituciones museísticas, y viceversa, y ha generado una particular interacción con las prácticas y circuitos artísticos contemporáneos. Las ideas que viajan entre "la práctica (artística) y la teoría (académica), y entre la práctica (académica) y la teoría (artística)" (Bal 27) han demostrado que es posible pensar en metodologías lo suficientemente flexibles "para facilitar la experimentación" también en el campo de la investigación histórica y el análisis cultural. En este sentido, los modelos de construcción de historia(s) se han transformado sensiblemente. De allí la importancia de acrecentar la reflexión acerca de las relaciones productivas existentes entre conocimiento histórico y ficción artística, a las que este artículo espera haber contribuido. 


\section{Obras citadas}

"Arte a sablazos: el duelo de ayer". El Argentino (Buenos

Aires), 26 de diciembre de 1891. Impreso.

A.Zul de Prusia [Max Eugenio Auzón]. "Bellas artes: la vuelta del Malón (cuadro del señor Á. Della Valle)". Sud América (Buenos Aires), 19 de julio de 1892, C. 3-1. Impreso.

A.Zul de Prusia [Max Eugenio Auzón]. "El crítico A.Zul de Prusia en la Exposición Artística". Sud-América (Buenos Aires), 12 de diciembre de 1891. Impreso.

Bal, Mieke. Conceptos viajeros en las humanidades: una guía de viaje. Murcia: Cendeac, 2009. Impreso.

Borges, Jorge Luis. "El duelo". El informe de Brodie.

Buenos Aires: Emecé, 1993. Impreso.

Foster, Hal. "An Archival Impulse". October 110 (Fall 2004): 3-22. Impreso.

Foster, Hal. "Archivos y utopías en el arte contemporáneo". Resistencia: Tercer seminario de teoría sobre arte contemporáneo. México: Patronato de Arte Contemporáneo, 2004. Impreso.

Foucault, Michel. "Las meninas". Las palabras y las cosas: una arqueología de las ciencias humana. Buenos Aires: Siglo XXI, 2003. 13-25. Impreso.

González, Valeria. Fotografía en la argentina: 1940-2010. Buenos Aires: ArtexArte-Fundación Alfonso y Luz Castillo, 2011. Impreso.

Malosetti Costa, Laura. Los primeros modernos: arte y sociedad en Buenos Aires a fines del siglo XIX. Buenos Aires: Fondo de Cultura Económica, 2001. Impreso.

Rancière, Jacques. "Estado de la política, estado del arte". Sobre políticas estéticas. Barcelona: Museu d'Art Contemporani, 2005. Impreso.

Rodríguez Carranza, Luz. "La destrucción fue mi Beatriz: Apátrida, doscientos años y unos días, de Rafael Spregelburd". Qorpus. Web. 2 de julio de 2014.

Rubinich, Lucas. "Vitalidad cultural en la sala de armas". Fanzine NSM 4/Te bato a duelo. Buenos Aires, 2012. Impreso.

Ruiz Palenzuelos, Ataliva. "Un duelo por amor al arte". El Hogar 23.934 (1927): 17 y 94. Impreso.

Sarlo, Beatriz. Introducción a El informe de Brodie. Borges Studies Online. J. L. Borges Center for Studies \& Documentation. Web. 1 de abril de 2014.

Sinclair, Marcela. "Saltar el cerco, hacia adentro". Blanco sobre Blanco. Miradas y Lecturas sobre Artes Visuales 4.6 (2014): 75-80. Impreso.

Spregelburd, Rafael. "Apátrida, doscientos años y unos meses".

Todo. Buenos Aires: Atuel, 2011. Impreso.

Spregelburd, Rafael. "Cuando lluevan uvas". Blanco sobre Blanco. Miradas y Lecturas sobre Artes Visuales (septiembre 2011): 66-75. Impreso. 
Spregelburd, Rafael. "Sé lo que se dirá de mí: entrevista a Rafael Spregelburd por

Dany Barreto". Sauna. Revista de Arte (mayo 2011). Web. 7 de julio de 2011.

Villanueva, Santiago. "Presentación de la muestra Pagano. El arte como valor histórico".

Buenos Aires: La Ene-Museo Energía de Arte Contemporáneo, julio 2014. Impreso.

Usubiaga, Viviana. "Del microfilm al escenario". Radar, suplemento cultural de Página 12 (Buenos Aires), 10 de abril de 2011: 7. Impreso.

Usubiaga, Viviana. "Pinceles, plumas y sables: la Exposición Artística de 1891".

AA. VV. Terceras fornadas Estudios e Investigaciones. Europa/Latinoamérica, Artes Plásticas y Música. Buenos Aires: Instituto de Teoría e Historia del Arte Julio E. Payró-Universidad de Buenos Aires, 1999. Impreso. 